\title{
Al-Mu'tazila Before Caliph Al-Ma'mun's Era
}

\author{
Dr. Mohammad Alesa \\ Khaled Aldafheeri
}

Al al-Bayt University, Mafraq, Jordan

doi: 10.19044/esj.2016.v12n32p330 URL:http://dx.doi.org/10.19044/esj.2016.v12n32p330

\begin{abstract}
Scholars in Al-Mu'tazila, and the dilemma of creating Qur'an that relates to it, was being used in studying various issues that is connected with the Abbasid caliphate Al-Ma'mun. This was without any deep search of its roots of more than a century before AL-Ma'mun's era. In this study titled “Al-Mu'tazila before Caliph Al-Ma'mun's era," we attempt to trace the initial precursors (I'tezal/seclusion), starting by AL-Qadariya which emerged as a reaction from Umayyad Jabriya to reaching Al-Ma'mun's taking power.
\end{abstract}

Keywords: AL- Qadariya, Al-Mu'tazila, Umayyad, Abbasid

\section{Introduction}

Consequently, we study the activity of Al-Mu'tazila before the era of Abbasid Caliphate Al-Ma'mun. In this research, we do not exert any effort to trace the activity of this school since it is just an idea on the mind until it is accomplished. Thus, it is considered to be an autonomous school.

Al-Qadariya had some ideas that are similar to that of Al-Mu'tazila. Al- Shahrastani, in his book titled "Kitabl Al-Milal Wa Al-Nihal (The Book of Sects and Creeds)," claimed that "Al-Mu'tazila have made the word (Destiny) to be a common one. Also, they declared that: the word "Destiny" is set for those who says that destiny, whether it is evil or good, comes from Almighty God (ALLAH) as a Provision for the stigma of title. This is because it was agreed upon the dispraise of such by the prophet's (PBUH) speech, saying "Al-Qadariya are the Magians of this nation" (AlShahrastani, 1975, v. 1, p.19).

Al-Baghdadi claimed that the Sunnites called them "Al-Qadariya" because they said that people who are responsible for making their deeds, and The Almighty God (ALLAH), has no deal with it (Ibn Al-Khatib, 1977, P.94).

The character of those Qadaris is Ma'bad Al-Juhan. He is Ma'bad Ibn Uwaimer Al-Juhani, one of the earliest Sophistic persons of Al-Basra. 
However, this was as narrated by Ibn Asakir that Al-Hajjaj Ibn Yusuf AlThaqafi has chosen him to be Abd Al-Malik ibn Marwan's messenger to the Roman. This was after Abd Al-Malik ibn Marwan asked Al-Hajjaj: "send me a scholar to send him to the Roman's King.” Despite that, Abd Al-Malik kept him as an educator and pedagogue for his son, Saied (Al-Hamathani, 1986, P. 196)

Ma'bad Al-Juhani was considered as one of the first persons who spoke about the Destiny's denial. Thus, this was narrated by Abu Al-Qasim Al Balkhi in his book (Fadl Al-I'tizal/ The Prefer of Seclusion). He stated: "The first one to speak about destiny and seclusion is Abo Younis AlAswari, a man from Al-Asawerah and is known as Sensweh; and his follower, Ma'bad Al-Juhani" (Al-Hamathani, 1986, P. 197).

Al- Shahrastani sees that Wasil ibn Ata, who is considered as the founder of the Al-Mu'tazila school, has followed the footprints of Ma'bad AlJuhani when he talked about the relationship between Ma'bad Al-Juhani and the beginnings of I'tizal/ seclusion. As a result, he said "the differences in the roots occurred at the end of The prophet's companions times, as a heresy by Ma'bad Al-Juhani, Gillan Damascene, and Younis Al-Aswari by sayings in destiny and denying, adding the good and evil to destiny; and Wasil ibn Ata has followed their way" (Al- Shahrastani, 1975, V.1, P. 28)

The historical resources mentioned that he participated in the revolution of Abd Al-Rahman ibn Al-Ash'ath. This was a revolution which was at first against Al-Hajjaj, but later it developed to be against the Umayyad State which was initially a dispute in correspondence between AlHajjaj and ibn Al-Ash'ath regarding the military strategy (Al-Tabari, 2003, V. 3, P. 622 \& Ibn Al-Atheer, 1997, V. 2, P. 309)' The revolutionists found in the revolution of ibn Al-Ash'ath, an opportunity to participate so as to express their dissatisfaction with the prevailing conditions during the period of Al- Hajjaj ruling in Iraq. Furthermore, this is in addition to the servants' (Al-Mawaly) feeling of oppression, especially after the recent growth of their numbers (Al-Eisa, 2013, P.7).

However, this revolution failed and Al-Hajjaj defeated them at the battle of Dear Al-Gamagem. All the participants of the revolution were punished, amongst them and the most famous of them were Sa'id bin Jubayr and Selim ibn Aswad Al-Muharbi who is called Abi Al-Sha'tha' Al-Kufi and others (Al-Tabari, 2003, V. 1, P. 643 \& Ibn Al-Atheer, 1997, V. 2, P. 316). Amongst others also was Ma'bad Al-Juhani.

The other person who followed Ma'bad in his thoughts was Gillan Damascene. Thus, Ibn Qutaiba said about him in his book Al-Ma'arf "He was a Qadari christen, no one spoke about destiny and claimed for it before him, except Ma'bad Al-Juhani.” 
Umar ibn Abdul-Aziz was about to kill him, but Gillan spoke about his ideas and announced his repentance. Thus, he came back to speak about the destiny's denial and exaggerated greatly during the days of Hisham ibn Abdul-Malik who was very stern on Al-Qadariya. However, Gillan showed a great adherence for his opinions after the death of Umar ibn Abdul-Aziz. As a result, Hisham ibn Abdul-Malik asked for him and brought Al-Awza'i to debate with him who issued a decree by killing him. As a result, he was hanged on Bab Kisan in Damascus (105 A.H / 723 A.C) (Ibn Qutaiba, 1992, P. 484 \& Al-Thahabi, 1971, V. 4, P. 424).

Al-Ga'd ibn Derham is considered to be one of the most important persons who spoke about destiny; thus, some of Umayyad Caliphates adopted and believed in his ideas (Al-Blathri, 1996, V. 4, P. 100 \& AlZahabi, 1993, V. 7, P. 337). Moreover, Marwan ibn Muhammad (the last Umayyad Caliph) when he was a governorate on Al-Gazera/the Island in the days of Hisham ibn Abdul-Malik, quoted him. Maybe he was his educator at childhood, and he was the first to claim the creation of the Holy Qur'an. Therefore, this appeared during his residency in Damascus. As a result, he was declared wanted in Bani Umayya, but he ran away and lived in Al-Kufa where he met Al-Jahm ibn Safwan who quoted many ideas from him. Then, Khalid ibn Abdallah Al-Qasri who was the ruler of Kufa, killed Al-Ja'd on the day of Sacrifice Feast in Kufa. Therefore, Khaled spoke to the people and said in his speech: "O people! sacrifice, then ALLAH may accept your sacrifices, and I will sacrifice by Al-Ja'd ibn Derham.” He claimed that Allah neither took Abraham as an intimate friend, nor Allah did spoke to Moses with a [direct] speech. ALLAH arose highly above what Al-Ja'd said; then he climbed down and slain him at the bottom of the pulpit (Ibn Kathir, 1988, V. 9, P. 382 \& Ibn Al-'Imad, 1986, V. 2, P.112). Additionally, Ibn Asakir added that then he climbed down and slaughtered his head with a knife (Ibn Asakir, 1996, V. 72, P. 100)

Furthermore, there was a plinth relationship between Muhammad ibn Marwan and Al-Ja'd ibn Derham. This was seen when Hisham ibn AbdulMalik ordered to kill Al-Ja'd when he was imprisoned in Khalid ibn Abdallah Al-Qasri's prisons in the middle of Iraq. Marwan ibn Muhammad did not like that order. As a result, he repressed his anger till he took the caliphate, entered Yazeed ibn Khalid Al- Qasri, and killed him in an ugly way (Al-Ketbi, 1973, V. 4, P. 127).

Al-Ja'd ibn Derham has proved the source for the saying of the Qur'an creation. Al-Ja'd had taken it from Aban ibn Sm'an who took it from Talut nephew of Labid. Also, Talut took it from Labid ibn A'sam, the Jewish who charmed the prophet (PBUH). Labid recited the Qur'an and spoke about the creation of the Bible (Ibn Asakir, 1996, V. 72, P. 100) Also, Labid took it from a Jewish in Yemen (Ibn Kathir, 1988, V. 9, P. 382). 
Then came Al-Jahm ibn Safwan, a student for Al-Ja'd. Literatures said that he was an exaggerator in his proposals (Sarh Al-Eyun, 1904, P. 293). Among the signs that Al-Jahm inherited from Al-Mu'tazila is the article of the occurrence of the knowledge of ALLAH. This shows that ALLAH's Knowledge is modern and ALLAH created it so. It was known and accepted by him that ALLAH may know all things before their existence by a knowledge that He creates (Sarh Al-Eyun, 1904, P. 293). Also, he spoke about the termination of the eternal Heaven and Hell. He opines that Faith is only knowing ALLAH, whereas disbelieving is ignoring ALLAH (Sarh AlEyun, 1904, P. 293).

Al-Jahm ibn Safwan deserved for these ideas the punishment of execution (128 A.H. / 745 A.C.), but Wasil has the greatest favor in setting the foundations of I'tizal/seclusion. Therefore, we cannot speak about ALMu'tazila without starting by him: he is Wasil ibn Ata' Abu Hudayfa alGazzal, the servant of Bani Dubba (Al-Safadi, 2000, V. 27, P. 245).

Wasil ibn Ata' is one of Al-Mu'tazila heads, but he is their first teacher. He spoke about Al-Khawarij when they accuse the major sin doer of infidelity: the fornicator is neither faithful nor an unbeliever. He is in between both ranks. Thus, as a result, Al-Hassan Al-Basri forced him out. Hence, they were called AL-Mu'tazila, and then Amr ibn Ubayd followed him, and were also called (Al-Thahabi, 1971, V. 8, P. 58).

Moreover, Wasil has various references. Nevertheless, the most important of them are; The meanings of Qur'an, the Book of repentance, the Book of Speeches, the Book of the rank in-between two ranks, the Book of The way to know the truth, the Book of what happened between me and Amr ibn Ubayd, the Book of categories of Al- Murji'ah, the Book of his speeches that uttered with no the letter $\mathrm{R}$, and the layers of Scholars and ignorant people, etc. (Al-Hamawi, 1979, V. 6, P. 2794).

However, these thoughts were represented in denying of destiny and the rank in-between two ranks and other thoughts of Al-Mu'tazila that prevailed at that time. On the other hand, the Umayyad State was suffering from weakness and was moving the fall forward (Al-Asfahani, 1998, V.3, P. 138).

Wasil made use of this condition and exerted no effort to send his missioners to the remote regions to spread Islam in the furthest of India, Turkestan, and Maghreb countries. He himself played a role in this regard and went to every horizon to preach Islam; thus, even about three thousand man became part of Islam through his effort (Al-Hamawi, 1979, V. 6, P. 2795).

Wasil assigned an efficient and qualified man to be in charge of spreading the thoughts of Al-Mu'tazila, such as Abdullah ibn Al- Harith (AlHamathani, 1986, P. 67), and Al-Kassem ibn Al-Sa'di, Ayoub ibn Al-Awtar, 
Hafs ibn Salem, Al-Hassan ibn Zakwan, and Uthman Altawil to Armenia (Isma'il, 1997, P. 95).

Subsequently, it is a must to ascribe the credit for setting up the basis of Al-Mu'tazila school to Wasil ibn Ata', as he has played a vital role in leading and managing it according to a clear doctrinally format (AlHamathani, 1986, P. 165). In addition, Wasil authored some intellectual books, but they are like the other works of Al-I'tizal. Thus, we only have the titles (Ibn Al-Murtada, 1961, P. 35) ' The most prominent works that got to us are; The Book of repentance, The Book of Qur'an Meanings, Al-Murji'ah categories, the Book of speeches concerning monotheism \& Justice, The Book of the way to knowing the truth, the Book of invitation, the Book of what happened between him and Amr ibn Labid, and the Book of the layers of Scholars and ignorant people (Al-Safadi, 2000, V. 27, P. 247).

Then, we move to another character of Al-Mu'tazila who prominently appeared during the age of Al-Ma'mun. His name is Amr ibn Ubayd (Ibn Khalkan, 1994, V.8, P.460). The author of the Book of Al-I'tizal surpass/ Fadl Al-I'tizal referred to a debate that was held between Wasil ibn Ata' and Amr ibn Ubayd that many historians ignored it. Thus, as a result of this, Amr turned to Al-I'tizal, and then Amr ibn Ubayd praised Wasil: "You see, if there is an angel or a prophet, he will be more than this one (Al-Hamathani, 1986, P. 235).

Amr ibn Ubayd was very strict in his saying about destiny, and there are many narrations about him that shows it. For instance, this can be seen in what was mentioned in the History of Baghdad that he replied on those who resort to texts to prove destiny (Ibn Al-Khatib, 1997, V. 12, P. 169).

When Al-Mansour took over power, he was afraid of Al-Mu'tazila because they supported many armed rebellions. For instance, Al-Mu'tazila supported the movement of Muhammad al-Nafs al-Zakiyya and Ibrahim, sons of Abdullah ibn Al-Hasan ibn Ali ibn Abi Taleb, Al-Asfahani mentioned at Al-Talebiyeen fights the moving between Al-Mu'tazila and Alshe'a "Wasil ibn Ata' who met Amr ibn Ubayd at the home of Uthman ibn Abd Al-Rahman Al-Makhzomi from Al-Basrah. Then they remembered injustice. Therefore, Amr ibn Ubayd said: “among those who do this issue and deserves it." Then Wasil said: "I swear to those who made it, the one who became the best of the nation, Mohamed ibn Abdullah Al-Hasan." Then Amr said: "I see that we shouldn't pledge allegiance, and it should be only with the one who we tasted, and have known his history." Then Wasil said: "By ALLAH, if Mohamed doesn't have a proof that proves his preference except that his father Abdullah ibn Al-Hasan, at his age, outshine, and position has found him efficient for this matter, and advanced him upon himself, so he deserves what we see for him, but what about Mohamed himself and his surpass? (Al-Asfahani, 2000, P.25). 
It is historical fact that Al-Mansour has tried to win over Al-Mu'tazila at the beginning of Abbasid Caliphate. Nevertheless, he has his reasons for this. The Caliphate is just at its raise and the opponent movements seek to have fallen the Abbasids and their State. As a result, Al-Mansour sent a request to Ibn Ubayd asking him to support the State: (Help me with your followers as they are justice full, honest companions, and influence full). Then ibn Ubayd replied: "if the flag of truth is raised, you will be exhausted by its followers (Ibn Abd Rabbih, 1982, V.3, P.190). Therefore, we refer here that the narration that was stated per the history of Baghdad and at the Book of Fada'el Al-'I'tizal were paraphrased (Ibn Al-Khateeb, 1997, V. 12, P. 168).

It will be right to say that Al-Mu'tazila under the leadership of Ibn Ubayd formed a marvelous force and had power and effect to send away some people who they see that they are in danger. Al-Gahiz mentioned that Bashar ibn Bard was sent away from Basra to Kufa by an order from Ibn Ubayd. Perhaps, Ibn Ubayd was able to do this only due to the numerous followers and his control on the intellectual and jurisprudence (Al-Gahiz, 2003, V.1, P. 35).

The forgoing mentioned as we addressed some characters of AlMu'tazila. They include: how was Al-Mu'tazila seen as a group? And what were their situations with the Umayyad Caliphate and the beginning of Abbasid State?

Since Al-Qadariya is the first basis of Al-Mu'tazila and the principles are the same that both parties called for it, therefore there is no escape from addressing Al-Qadariya that considered Umayyad State which ripped the Caliphate. As a result, they participated in the Revolution of Abd Al-Rahman ibn Al-Ash'ath (83-83 A.H. / 700 - 702 A.C) (Al-Tabari, 2003, V.6, P. 334). There was a revolution of Al-Harith ibn Sarih Ali Hisham ibn Abd El-Malik (116A.H / 724 A.C) (Abd Al-Daiyem, 2016). Al-Harith was called to get rid of injustice, to work by the Holy Qur'an and the prophet's Sunnah, to employ the qualified and fair justice, and to return back to Shura (Imara, 1997, P.80). There was a revolution of Zaid ibn Ali against Umayyad Caliph Hisham ibn Abd Al-Malik in (122A.H/ 739 A.C) (Al-Shahrastani, 1975, V.1, P.154). AlMu'tazila considered that Zaid is a leader from Al Al-Bait who adopted their school. He also made a revolution against an injustice Caliph. As such, he deserved being with him against injustice and distributing money fairly, and taking revenge for $\mathrm{Al} \mathrm{Al-Bait} \mathrm{who} \mathrm{were} \mathrm{tortured} \mathrm{greatly} \mathrm{in} \mathrm{the} \mathrm{hands} \mathrm{of}$ Umayyad.

When Yazeed ibn Al-Waleed rebelled against his uncle, Al-Waleed (126A.H / 743 A.C), Al-Mu'tazila were among the participants till he accomplished the victory of Yazeed and took Caliphate. After then, he 
declared returning to Shura and declared the right of Muslims in changing the Caliph if he ruled unfairly (Al-Mas'udi, 1988, V.2, .176).

Umayyad Caliph, Yazeed ibn Al-Waleed ibn Abd Al-Malik, is the first caliph to adopt the five fundamentalist of Al-Mu'tazila. As mentioned above, Al-Mu'tazila supported him till he took over the caliphate (AlMas'udi, 1988, V.6, P.20). Yazeed was guided through Al-Mu'tazila thoughts and tried to apply Islamic Sharia. Also, the heads of Al-Mu'tazila reached great positions and took control of authority affairs and led him according to their principles. They even suggested to the Caliph to choose his governors from those who are like him in religion and piety (Al-Tabari, 2003, V.9, P.44).

Al-Mu'tazila found the best opportunity to participate in the revolution of Yazeed and in applying their principles after they recognized the debauch of Al-Waleed and the justice of Yazeed. Al-Shahrastani mentioned that Amr in Ubayd was one of the callers of Yazeed Al-Nakes during the days of Umayyad. Thus, he described him: Al-Kamil who said per justice and applied justice, exerted himself, killed his cousin as a worship to God, and was tortured because of his relatives, and deducted from their gifts what the titans increased for them, and showed the innocence of his parents (Al-Shahrastani, 1975, V.1, P. 30).

Yazeed didn't stay too long at Caliphate no longer than six months. Then his brother Ibrahim succeeded him for a period ( of two months) (in 127 A.H / 745 A.C). Countries were full of putsches and riot at that time; thus, caliphate at this time has lost its respect and dignity. Others called him governor, while some called him with no title (Ibn Al-Atheer, 1997, V.5, P.115). Then, Marwan ibn Mohamed became caliph at Damascus and forced Yazeed to dethrone himself and waive the caliphate (Ibn Al-Atheer, 1997, V.4, P.331).

After the fall of Umayyad, the Abbasid State raised, we noticed that Al-Mu'tazila took part in Al-Alawyeen hereditary. Hence, we referred to this before when we talk about the characters of Al-Mu'tazila to the support of Al-Mu'tazila for the revolution of Mohamed Al-Nafs Al-Zakiyya at the days of Abi Ga'far Al-Mansour. After the death of Al-Mansour, his son, AlMahdi, took power and there was no reference about any activity for AlMu'tazila during his time. Particularly, Al-Mahdi was strict with fancy people (Al-Sabhani, 1996, P.253). This could be due to some important reasons in addition to the strong character that the earliest caliphs had at the golden Abbasid era, lunching Al-Alawyeen revolutions after the caliphate went to Abbasid such as the revolution of Mohamed Al-Nafs Al-Zakiyya and his brother Ibrahim. Moreover, the nature of intellectual thinking of AlMu'tazila that tends to release the ideas as argumentations apart from absorption at armed movements, one of the big differences among Al- 
Mu'tazila and the other schools at its time or before it, was the politics that played a little role according to these schools. Al-Mu'tazila had certain political point of view. Also, Al-Mu'tazila in Baghdad had relations with the guardians and leading characters in power (from 200-230 A.H / 815-845 A.C). Furthermore, we looked at Al-Mu'tazila that they are unlisted among the leaders of Al-Mu'tazila. Also, we found that they could be nearly theologians during our era. Perhaps, their defense of Islam against Manichaeism and Indian Husain had a touch of political calling since it was at first a defense for caliphate and its pillars or its basics that make its raise a must (Watt, 1998, P.122). Then at the time of Al-Rasheed, Al-Mu'tazila had played an insignificant role. However, Al-Rasheed didn't give room for philosophers. Ibn Al-Murtada said: Al-Rasheed prohibited philosophy and ordered the imprisonment of philosophers (Ibn Al-Murtada, 1961, P.55). Among those who were famous at the time of Haroun Al-Rasheed include; Bishr ibn Al-Mu'tamir sheikh of Al-Mu'tazila and one of the important readers to whom ended the presidency of Al-Mu'tazila at his time. In addition, he was a narrator for poetry, news, and a poet; also, the Al-Bshriya Group of Al-Mu'tazila was entitled after him (Al-Thahabi, 1971, V.16, P.472).

Therefore, per the forgoing, we can say that Al-Mu'tazila stayed in shadow at the time that preceded Al-Ma'mun. They didn't come to light clearly since they took the appropriate propaganda to be their methodology. From time to time, they supported revolutions against Umayyad and Abbasid States, particularly revolutions of Shiism. This is attributed to the fact that due to the close ideas among them, some deeply intellectual and scientific characters emerged from them and they had a great scientific production. Therefore, this will lead us to speak about Al-Mu'tazila and their role at the time of Al-Ma'mun.

\section{References:}

1. Shahrastani , Mohammed bin Abd Al kareem (548A.H/1153A.D) Al-Milal Wa Al-Nihal, Dar ALmaarefa.Bierut. 1975

2. Al-Baghdadi,Abd Alkader Bin Taher(429A.H/1037A.D) ALfark Baen ALferak. Modern Library. Bierut.1990

3. Al-Hamathani, Abd Aljabbar Bin Ahmed (415A.H/1024A.D) Fadel ALeitizal wa Tabakat Al-Mu'tazila,Word reference, fwad sayed, Aldar Altuneseya,Tunes 1983.

4. Al-Tabari, Tareekh, Mohmemd Bin Jareeer (310A.H/922A.D) Alrusel wa ALmuluk, Word reference Nawwaf ALjarrah, Dar Saader.Bierut,2003. 
5. Ibn Al-Atheer,Mohammed Bin Abd Alkareem ALshaebane (630A.H/1232A.D) ALkamel fi ALtareekh, Word reference Omar Tadmuri.Dar ALkitab ALaraby, Bierut, 1997.

6. Al-Eisa, Mohammed, Role of Readres in Ibn ALashath Revolution, ALmanar Journaly. AL ALbayt University, 2013.

7. Ibn Qutaiba, Abdullah Bin Muslim (276A.H/889A.D) ALmaaref, Word reference THarwat okasha, Egyptian Commission for Books, 1992.

8. Al-Thahabi, Shams ALdeen Mohammed Bin Ahmed (748A.H/1347A.D) Lesaan ALmeezan, ALaalame Institute, Bierut,1971.

9. Tareekh ALislaam wa Wafeyat ALmashaheer wa ALaayan, Word reference Omar Tadmuri.Dar ALkitab ALaraby, Bierut, 1993.

10. Al-Blathri, Ahmed Bin Yahea (279A.H/892A.D), Ansaab ALashraaf, Word reference Suhayl Zakkar,1996.

11. ALzahab fe Aqbaar Man Zahab, Ibn Al-'Imad, Abd ALhai Bin Ahmed (1089A.H/1678A.D) SHazara, Word reference Mahmood ALarnaut, Dar Ibn Qatheer, Damascus, 1986.

12. Ibn Asakir, Ahmed Bin Mohammed Bin Hibat Allah (610A.H/1213A.D) Tareekh Damascus. Word reference Muhib ALdeen ALamrawe, Dar ALfekr, Bierut 1996.

13. Ibn Kathir, Ismaaeel Bin Omar (610A.H/1213A.D) ALbidaeah wa ALnihayah, Word reference Ali SHeere, Dar Iheai ALturaath ALaraby, Bierut, 1988.

14. ALkutbi, Mohammed Bin Shaker (764A.H/1363A.D) Fawat ALwafeyat, Word reference Ihsaan Abbas, Dar Sader, Bierut, 1973.

15. Ibn Zaydoon, Ahmed Bin Abdallah (463A.H/1072A.D) Sarh AlEyun, Explain Ibn Zaydoon Lettre, 1904

16. Al-Hamawi, Yaaqoot Bin Abdallah (626A.H/1229A.D) Muajam ALbuldan, Dar Ihiaa ALturaath ALaraby, Bierut, 1979.

17. Alasfahani, Abu ALfaraj (356A.H/967A.D) ALaganee, Word reference Sameer Jaber , Dar ALfekr, Bierut 1998.

18. Isma'il, Mahmood, Secret Movemments In Islaam, Dar ALintishar ALaraby, Bierut 1997.

19. Ibn Al-Murtada, Ahmed Bin Yahia (840A.H/1437A.D) Tabaqat ALeitezal , Word reference Susana David Feelers, 1961.

20. Ibn Khalkan, Ahmed Bin Mohammad Bin Ibraaheem (680A.H/1282A.D) Wafeeat ALaayan, Word reference Ihsaan Abbas, , Dar Saader.Bierut,1994.

21. Ibn Al-Khatib,Ahmed Bin Ali Bin THabet (463A.H/1072A.D) Tareekh Baghdad waTHiuleh, , Word reference Mustafa Abd ALqader Ata,Dar ALkutub ALilmeia, Bierut 1997. 
22. Alsfahani, Ali Bin ALhussein (356A.H/967A.D) Maqatel ALtalebeein, , Word reference Ahmed Saqer, Dar ALmaarefa, Bierut 2000.

23. ALandaluse, Ahmed Bin Abd Rabbu (327A.H/938A.D) ALeqd ALfareed, .Dar ALkitab ALaraby, Bierut, 1982.

24. Abd ALdaeim, Noor, Gillan Damascene, Master Degree, ALL ALbait University.2016.

25. Omara, Mohammed, Islamic Movement Idiaology, Dar ALshoroq, Qairo, 1997.

26. Al-Mas'udi, Ali Bin ALhussein (346A.H/957A.D) Murooj ALzahab wa Maaden ALjawhar, , Word reference Mohammed Muhie ALdeen Abd ALhameed, Modern Library. Bierut 1988.

27. Al-Sabhani, Jaafer Bin Mohammed, Buhooth Fi ALmilal wa ALnihal,Teachers Group, Qum 1996.

28. Montgomery Watt,Fate And Destiny In Islam, Translation Abd ALrahmaan ALshiek, Egyptian Commission for Books, Cairo 1992. 